\title{
Characterization of Structural Damage on the Facade of Colonials Houses in Cartagena
}

\author{
Walberto Rivera Martínez* \\ University of Cartagena, Cartagena Colombia, Faculty of Engineering, Civil Engineering Program, \\ walbertorivera@yahoo.es
}

\begin{abstract}
Objectives: This research was conducted in order to characterize the structural damage of the facades of colonial houses in the historical center of Cartagena (Colombia). Methods: Such objective was achieved by means of a descriptive bibliographical research, along with field data collection, photographic records and analysis results by sampling. The study sample consisted of 100 of the most representative colonial houses whose typology had remained unaltered; 42 of them were grouped as Low Houses (LH) and 58 as High Houses (HH). Mechanical, chemical and physical structural damages were identified for different parts of the facade houses. Findings: Fouling and erosion were the most common physical structural damages found in the colonial houses; the highest results of them were obtained for walls, in which fouling was presented in $95.24 \%$ of the $\mathrm{LH}$ and erosion damage exposed $82.76 \%$ of the HH. Walls also presented the greatest mechanical structural damage, where fissures reached $85.71 \%$ of the LH. Finally, the chemical structural damage most meaningful was fungi found in the walls of the $\mathrm{HH}$, exposing $74.34 \%$. This research makes a great contribution since a study like this had not been made before for the colonial houses in Cartagena. Application/Improvements: The results obtained in this report would provide pertinent institutions with enough data to facilitate the selection of proper interventions to be applied in the houses.
\end{abstract}

Keywords: Characterize, Colonial House, Heritage, Pathology, Structural Damage

\section{Introduction}

The colonial houses in the historical center of Cartagena (Colombia) $\left(10^{\circ} 25^{\prime} 25^{\prime \prime} \mathrm{N} 75^{\circ} 31^{\prime} 31^{\prime \prime} \mathrm{O}\right)$ confer historical value to the city. The constructive form, the materials that were used and the age of these houses are some of the factors that provide them with great architectonic value nowadays. This one of the reasons why the city was declared as Historic Herigate by the UNESCO. The first houses inhabited by colonists arriving to Cartagena in the XVI century were built with bahareque, wood and tablazon $\stackrel{1-3}{ }$. However, a fire in 1552 forced the inhabitants of the city to start building their houses with fire and weather-resistant materials, such as, coral stone, wood, lime and bricks, among others 2,4 .

As the years went by, houses that were built during colonial times, as many other buildings, suffered from different pathologic processes which slowly caused damages to their structures. In $^{5}$ classified theses damages by the origin of their causes: physical, mechanical and chemical. Based on this classification it can be affirmed that the city's environment contains most of the key factors that can influence the occurrence of damages in the facade of colonial houses. For this reason, is important to put into context the historical center of the city, which is composed by the neighborhoods of El Centro, San Diego and Getsemaní (Figure 1), it is surrounded by the Caribbean Sea, the monthly average of rain ${ }^{6.7}$ is set at 51.4 $\mathrm{mm}$, the phreatic level ${ }^{8}$ fluctuates between 0.8 and $1.5 \mathrm{~m}$, the annual average of relative humidity in the city is $83 \%$, predominant winds in the city blow from the North and North East.

Given the great importance of the historical center and their buildings to Cartagena, there is a clear need of

${ }^{*}$ Author for correspondence 
a diagnose which clearly indicates the way time, nature forces and human activities have affected the structural behavior of these houses. This research consisted of a characterization of the recurring pathology in the structure of elements belonging to the facade of colonial houses. Such technique provides pertinent institutions with enough data to facilitate the selection of proper interventions and maintenance to be applied.

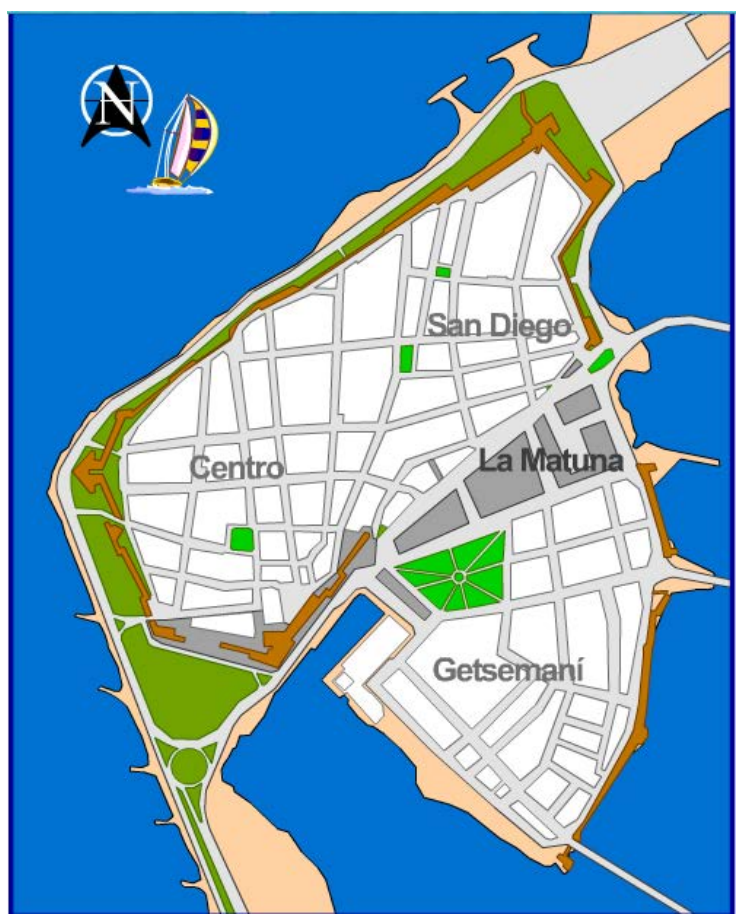

Figure 1. Map of Cartagena historical centerํ․

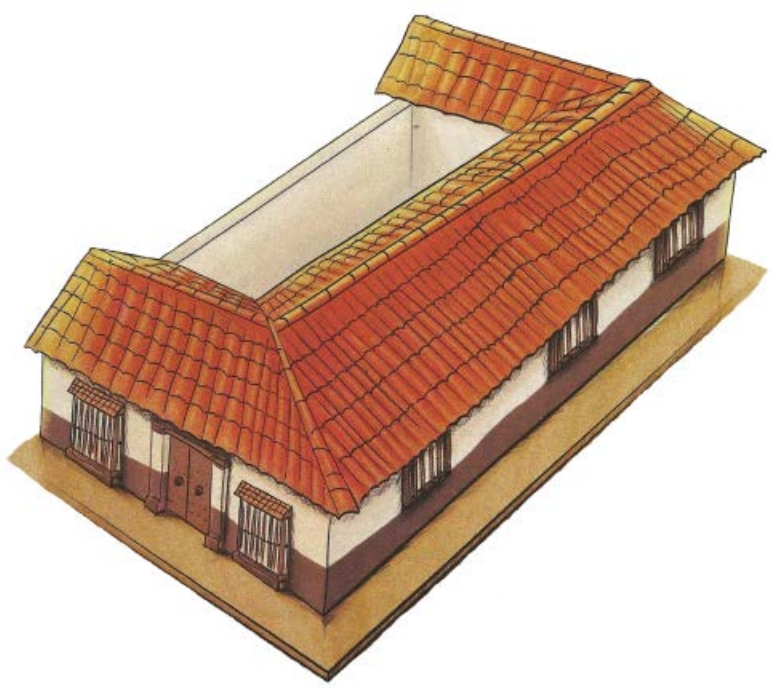

Figure 2. Isometric view of the low colonial house ${ }^{2}$.
Table 1. Structural damages classification

\begin{tabular}{|l|l|}
\hline Structural damage type & Damage \\
\hline \multirow{5}{*}{ Physical } & Accidental Moisture \\
\cline { 2 - 2 } & Moisture by Filtration \\
\cline { 2 - 2 } & Condensation Moisture \\
\cline { 2 - 2 } & Capillary Moisture \\
\cline { 2 - 2 } & Fouling \\
\cline { 2 - 2 } & Erosion \\
\hline \multirow{5}{*}{ Mechanical } & Deformations \\
\cline { 2 - 2 } & Fissures \\
\cline { 2 - 2 } & Cracks \\
\cline { 2 - 2 } & Detachments \\
\hline \multirow{5}{*}{ Chemical } & Efflorescence \\
\cline { 2 - 2 } & Animals \\
\hline & Plants \\
\cline { 2 - 2 } & Mold \\
\cline { 2 - 2 } & Fungi \\
\hline
\end{tabular}

\section{Methods}

This was a mixed, bibliographical-descriptive research with field data collection. No laboratory testing was involved during the characterization of the studied elements. Instead, each pathology was identified based in the classification ${ }^{5}$ shown in Table 1 . This project found the most frequent physical, mechanical and chemical structural damages that promote the deterioration of 58 high

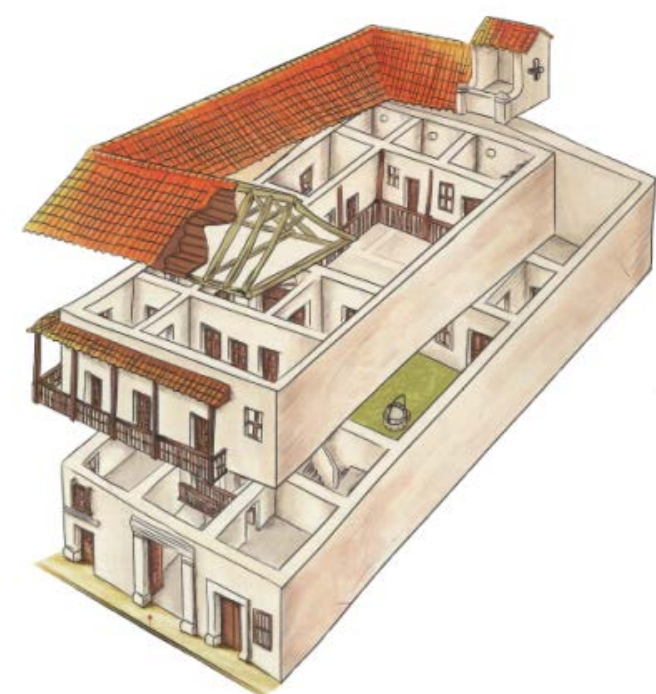

Figure 3. Isometric view of the high colonial house ${ }^{2}$. 
(HH) and 42 low (LH) colonial houses and their different parts (walls, windows, fronts, doors, balconies and roof shingles), as it can be seen in Figures 2 and 3, LH have not balconies and roof shingles compared to HH. 58 of the buildings were located in el Centro (52 of them were $\mathrm{HH}), 16$ in San Diego and the remaining 26 in Getsemaní.

Size of the sample was determined by visual inspection with the help of a plot plan showing the different blocks where all the colonial houses were located. Once the total size of the population was known, sampling size (n) was calculated with the formula:

where, Nis the total population, is a coefficient that depends on certainty, $p$ is the expected proportion, $d$ is the accuracy and $q$ represents the next subtraction $1-p$.

\subsection{Data Collection Techniques}

Figure 4 shows the activities followed in this research for the collection of data needed.

\subsection{Techniques for Data Analysis}

Each type of damage was classified and qualified based on the schemes of damage surveys and the photographic evidence. The objective was to achieve a proper characterization that would allow the identification of damages. Finally, all collected data was transcribed and analyzed in an inspection report.

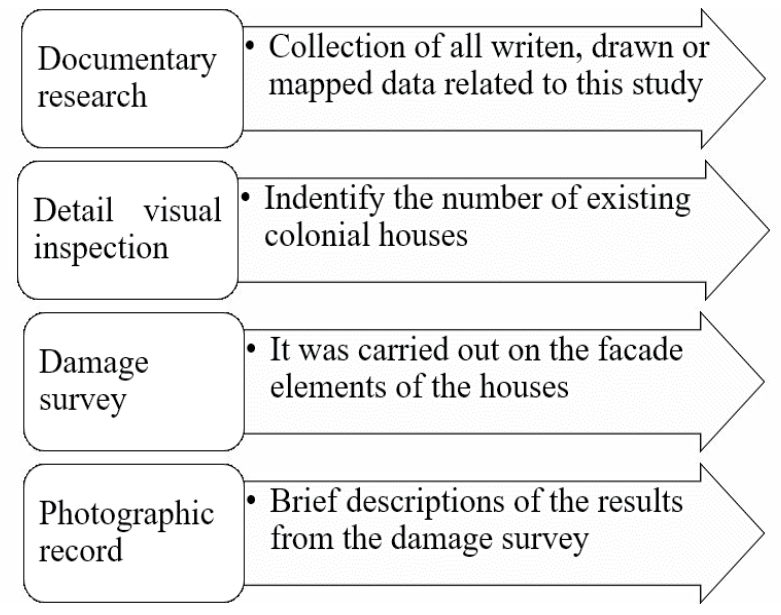

Figure 4. Data collection procedure.

\section{Results and Discussion}

An initial inspection was carried out with the purpose of determining the number of colonial houses in the his- torical center. 255 potential buildings were identified; 159 of them were selected after considering the convenience of their locations, the presence of nomenclature in their facades and their pathological representation. Once the 159 colonial houses had been selected under the previous criteria, a statistical analysis (Equation 1) was executed in order to determine the number of houses that would be useful for the characterization. The result was a group of 100 houses with an expected proportion of 5\%, 3.5\% accuracy and 95\% certainty (1.96). These target houses were selected among the most representative ones of each neighborhood in the historical center of Cartagena.

\subsection{Ratio of Physical Structural Damages in Facade of Colonial Houses}

As it can be seen in Figure 5, fouling is the phenomenon which affects both types of houses in their walls the most ( $>90 \%$ ratios), followed by wind erosion. There are two types of fouling that affect the facade of colonial houses: by deposit and by differential wash. The first is caused by winds (North and Northwest) that blow toward the city, while the second is caused by rain. Capillary moisture and moisture by condensation were more frequently observed in the walls of $\mathrm{HH}$. It should be noted that this type of house is located in the sector El Centro, which is constantly exposed to the direct action of winds.

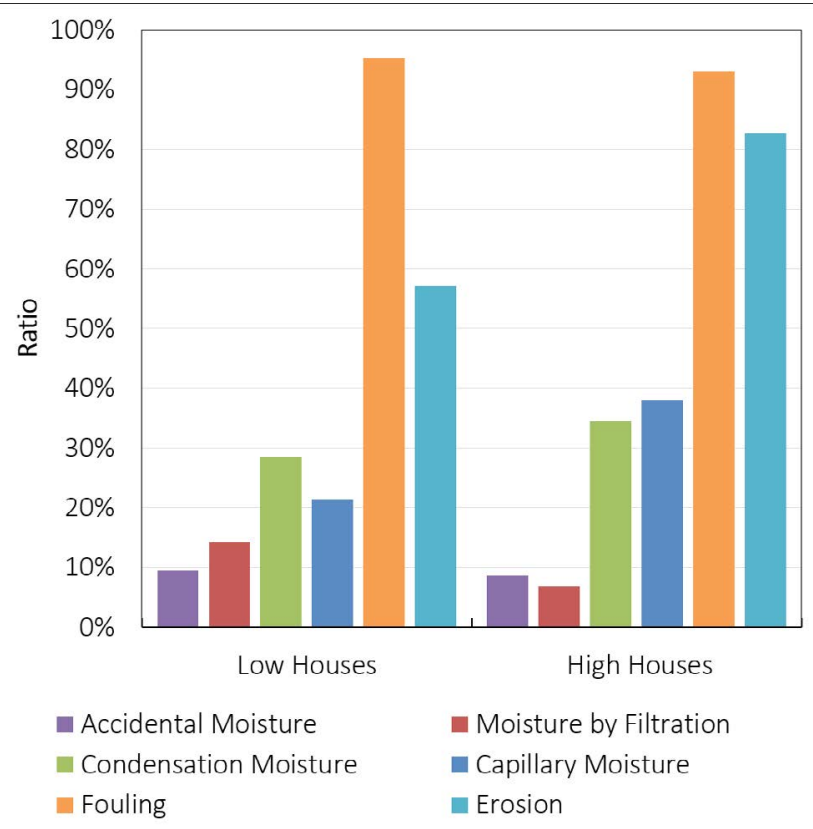

Figure 5. Physical damages on the walls of colonial houses. 
Winds and rainfall intensity are the main cause of the erosion exhibited by the facade of colonial houses. Capillary moisture is more frequently found in high houses because of their location, and due to the fact that the phreatic level of the sector is influenced by high tides. The walls of houses in El Centro are highly exposed to the local environment, since they have large contact areas.

The windows on the facades of colonial houses did not present major physical damage in their structure, except for fouling in $\mathrm{LH}$ which exceeded by $40 \%$ of the ratio in $\mathrm{HH}$ (see Figure 6). This damage has become an unavoidable fact, because of the particles that wind carry with it.

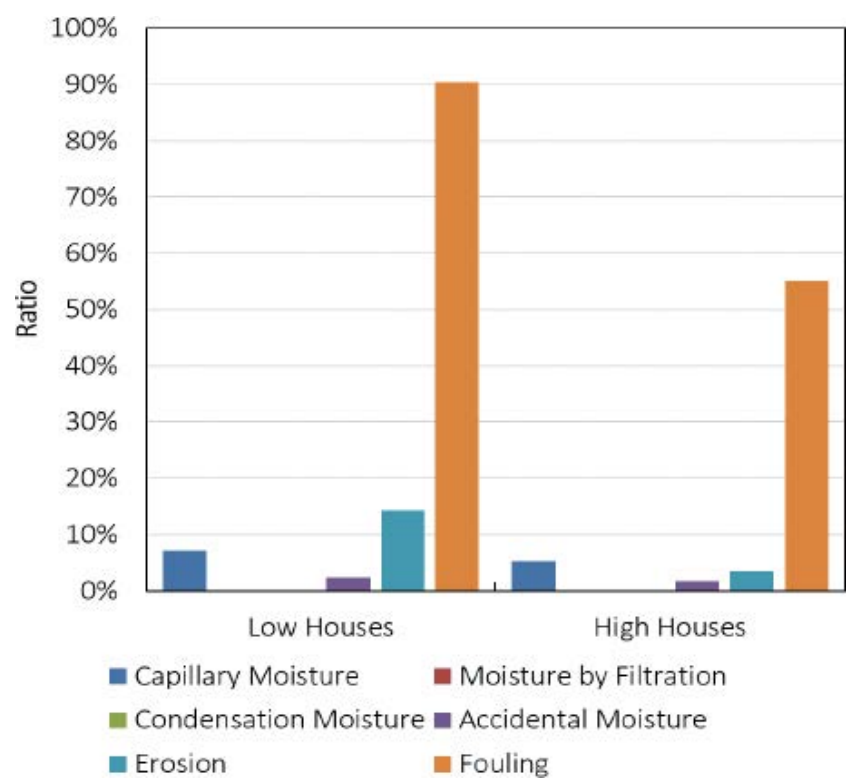

Figure 6. Physical damages on the windows of colonial houses.

The high concentrations of fouling material in the atmosphere promote the degradation of fronts, especially when the structure presents high levels of porosity. Based on Figure 7 it can be highlighted $86.5 \%$ of the total houses presented fouling in their fronts, in general, physical damages in both types of houses exposed similar ratios.

Ratios shown in Figure 8 are similar to those obtained for windows and fronts. Fouling of the doors ( $>80 \%$ of the total houses) is caused by the lack of periodical cleaning or the presence of corrosion in metallic elements of the building. The lack of proper painting can also lead to fouling.

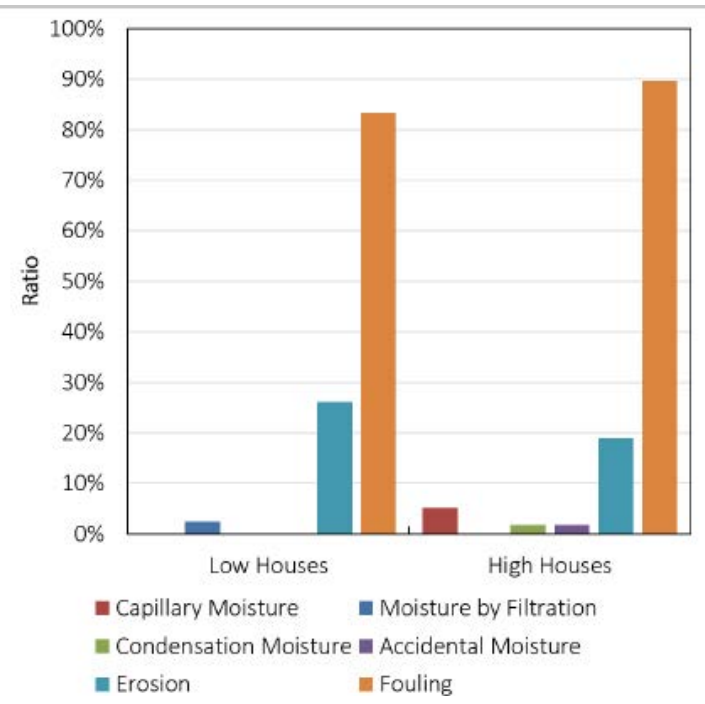

Figure 7. Physical damages on the fronts of colonial houses.

Physical damages in balconies presented higher ratios than those shown before. Fouling is again the highest damage found in this part of colonial houses. Size of the fouling material plays an important role, since it determines the residence time of atmospheric suspension, as well as the way it adheres to the balconies: through dry process (wind) or wet process (rain).

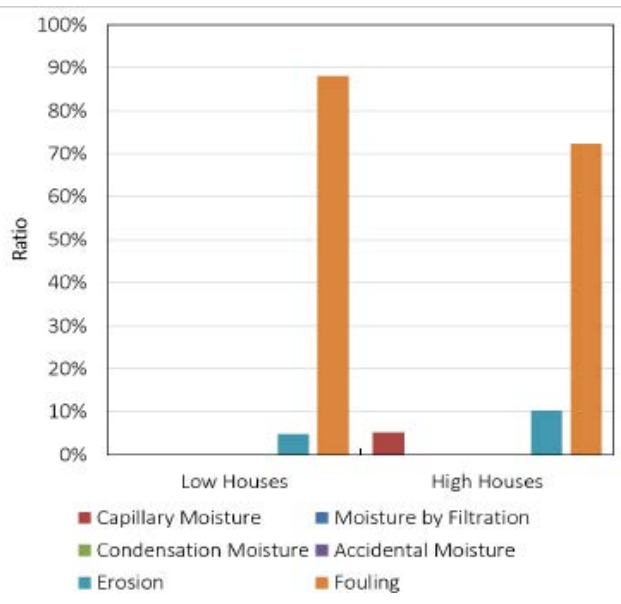

Figure 8. Physical damages on the doors of colonial houses. 


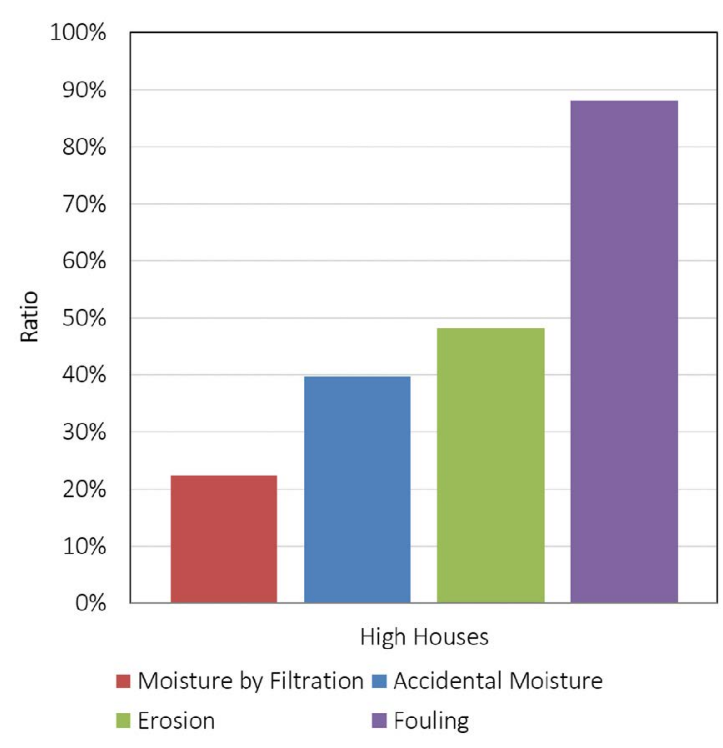

Figure 9. Physical damages on the covered balconies of colonial houses.

Fouling was presented in $86.21 \%$ of roof shingles, additionally it is important to highlight the ratio of moisture by filtration in Figures 9 and 10 (24.14\%) which is the highest result of this damage obtained. Fouling of the roof shingles is closely related to other damages with chemical origin. For instance, the fouling material that adheres to the shingles can react with certain components of their structure.

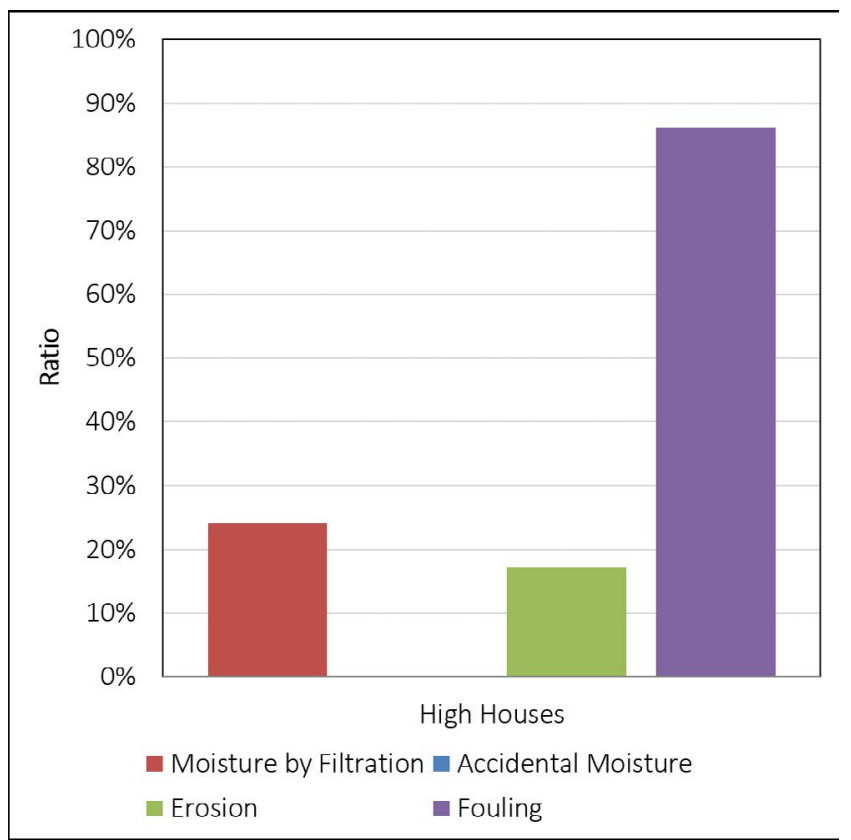

Figure 10. Physical damages on the roof shingles of colonial houses.

\subsection{Ratio of Mechanical Structural Damages in Facade of Colonial Houses}

Most of the walls of $\mathrm{HH}$ and $\mathrm{LH}$ in the historical center exposed fissures (Figure 11). Other damages such as cracks and detachments affected high amounts of the colonial houses. The occurrence of fissures and cracks is due to the application of a direct load on a construction element which implies a deformation. This phenomenon causes most part of the damages in structural elements and materials.

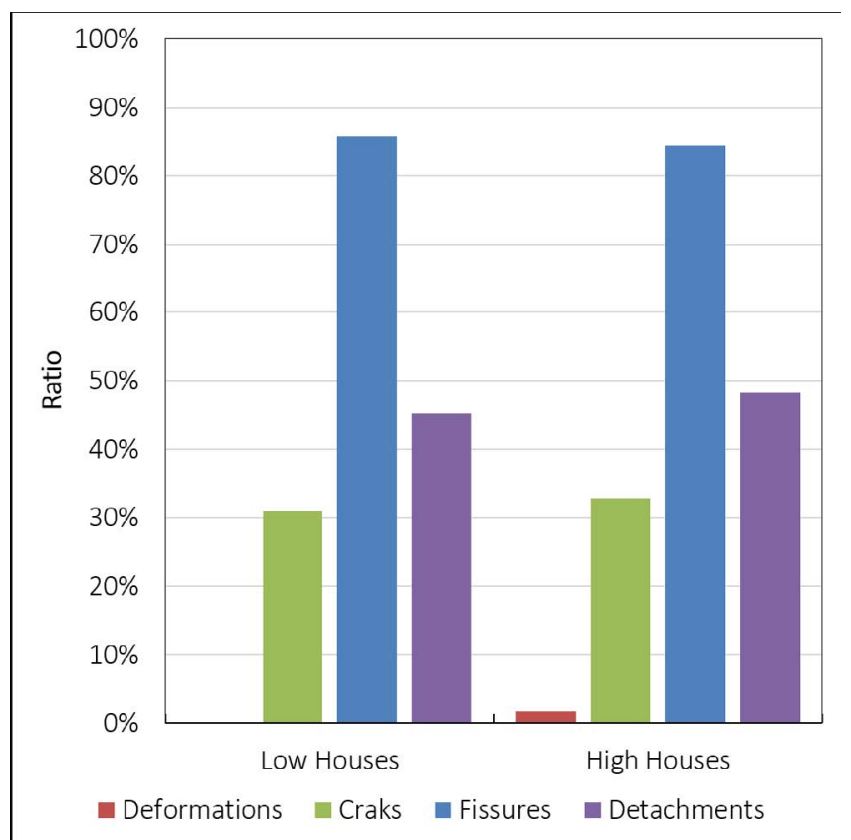

Figure 11. Mechanical damages on the walls of colonial houses.

Windows of $\mathrm{HH}$ obtained low ratios of mechanical damages; the highest values shown in Figure 12 for LH corresponded to $30.95 \%$ for detachments and $21.34 \%$ for fissures. Detachments of the materials that compose facades are a common occurrence in colonial houses. Such damages are often produced as a result of previous conditions such as deformations, fissures or cracks.

Fissures and detachments are common damages in the fronts of $\mathrm{HH}$ and $\mathrm{LH}$, as it can be seen in Figure 13 the ratios for $\mathrm{LH}$ are higher than for $\mathrm{HH}$. The stones that were used as building material for the front of colonial houses exhibit a widely heterogeneous nature. Thus, it is possible to find significant variations in texture and porosity of the material. 


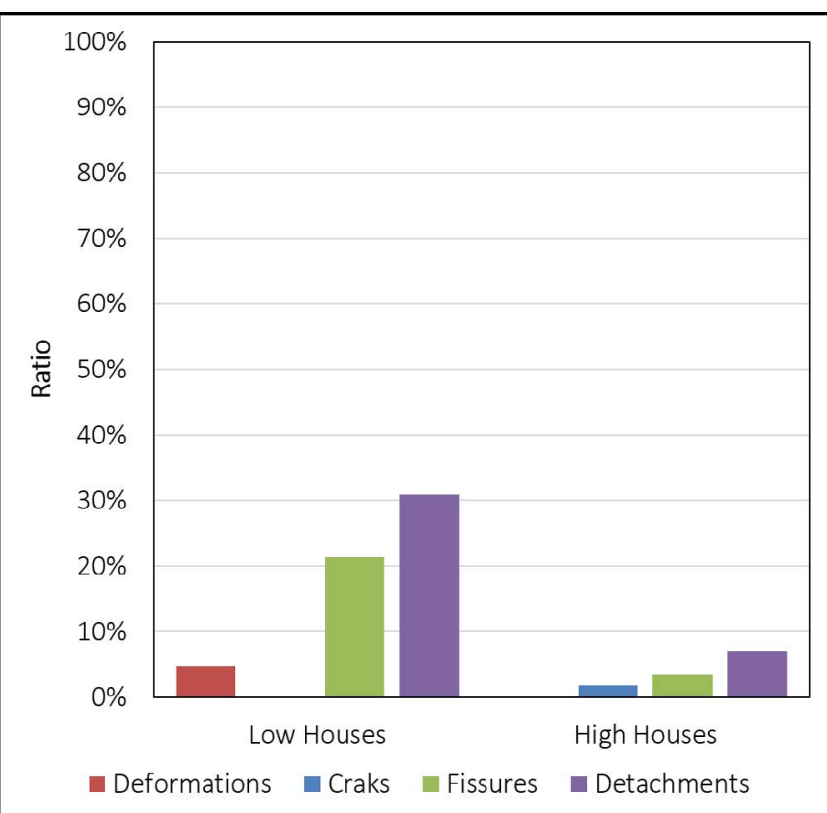

Figure 12. Mechanical damages on the windows of colonial houses.

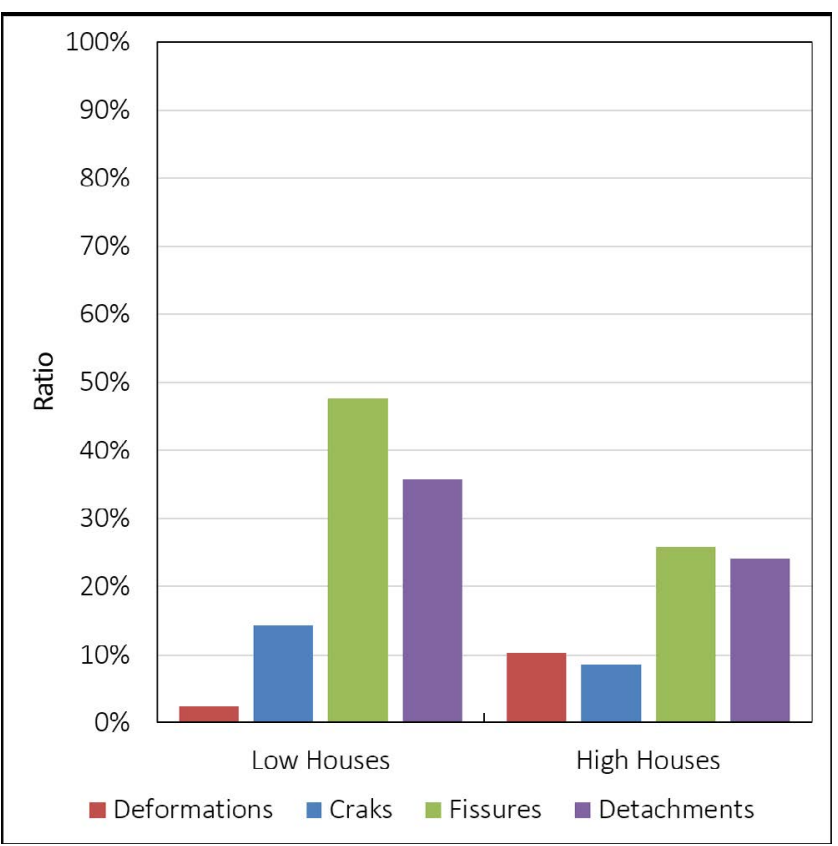

Figure 13. Mechanical damages on the fronts of colonial houses.

Doors exposed low ratios of mechanical damages (Figure 14), detachment of doors in LH were the highest ratio $23.81 \%$. This damage is caused by the fixation system and the freedom of individual movement between its pieces. Loosening can happen as a result of two major causes: the use of inappropriate fixations and defects in the base of doors.

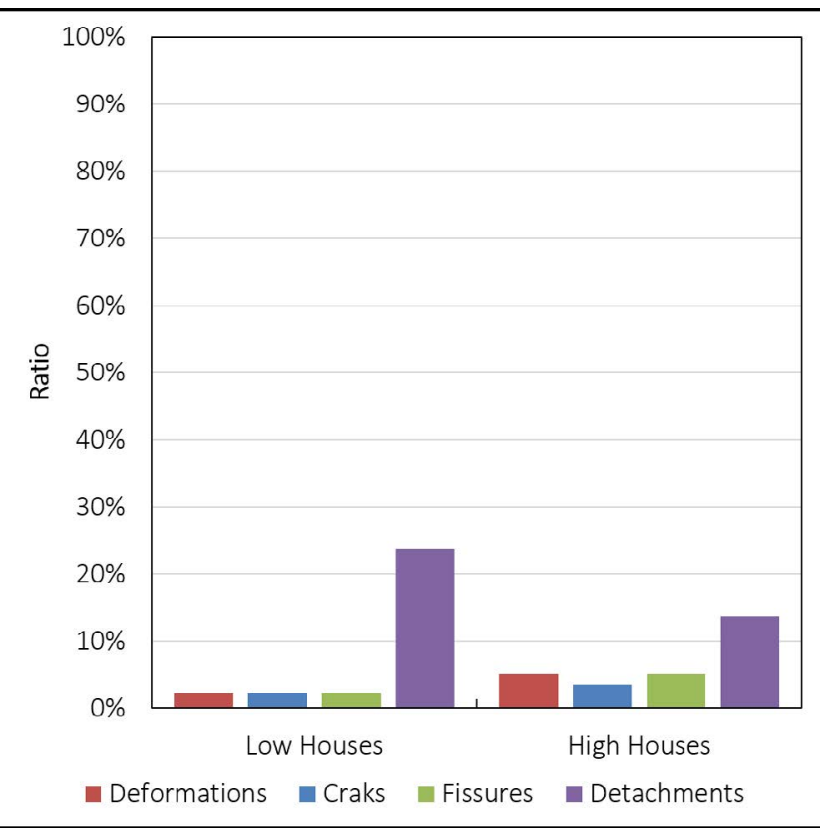

Figure 14. Mechanical damages on the doors of colonial houses.

Balconies generally made of excellent wood which limit degradation down to an isolated extent. Many old constructions were built using heartwood, which can only be attacked by termites. In these structures were found ratios between $28 \%$ and $40 \%$ for deformations, cracks and fissures. Detachments were found in $51.72 \%$ of the balconies in colonial houses (Figure 15).

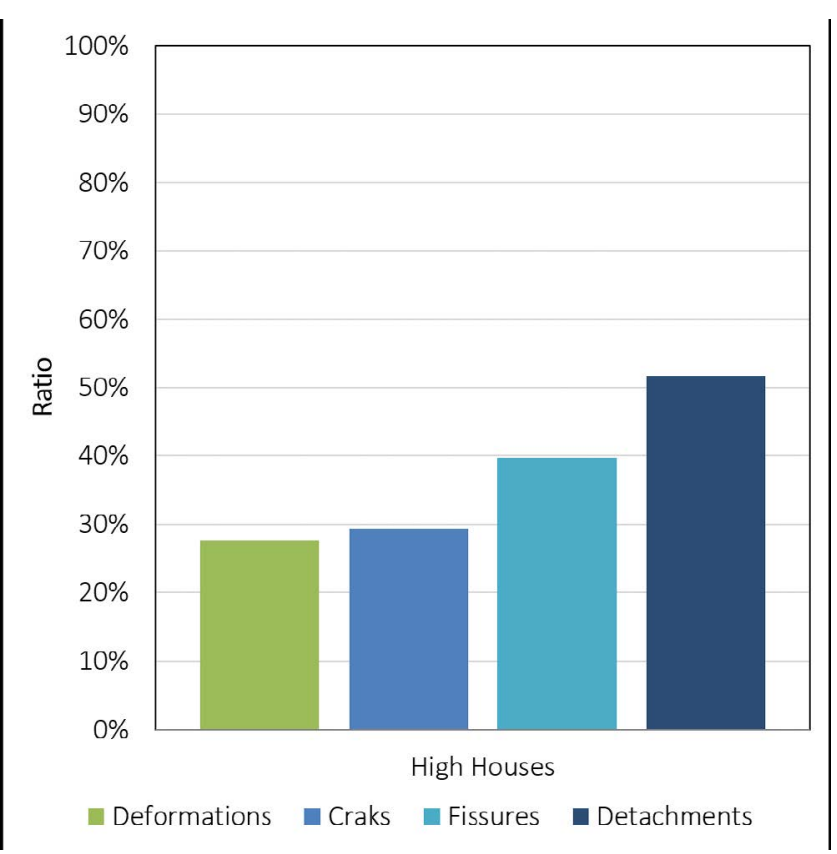

Figure 15. Mechanical damages on the covered balconies of colonial houses. 
As it has been shown in this section, detachment is one of the more recurrent mechanical damages in different structures of the houses (Figure 16), 36.21\% of roof shingles were affected for this damage over the time which can be caused by micro fissures during their construction.

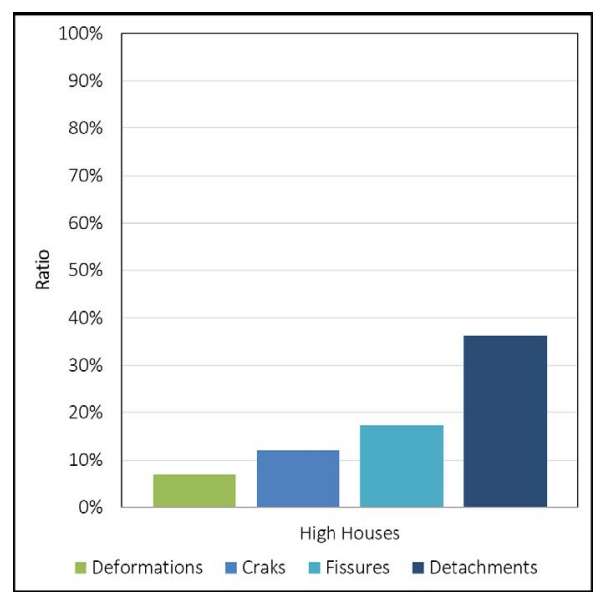

Figure16. Mechanical damages on the roof shingles of colonial houses.

\subsection{Ratio of Chemical Structural Damages in Facade of Colonial Houses}

Walls are the most exposed structure of the colonial houses, as it can be seen in last sections, they presented the higher ratios for each type of damage, and in particular, for chemical damages, bio-responsiveness on the surface of the walls and proliferation of microorganisms are two of the major factors that affect the facades. Fungi were the highest ratio obtained in walls of houses. Figure 17 shows $>70 \%$ for fungi and $>55 \%$ for efflorescence.

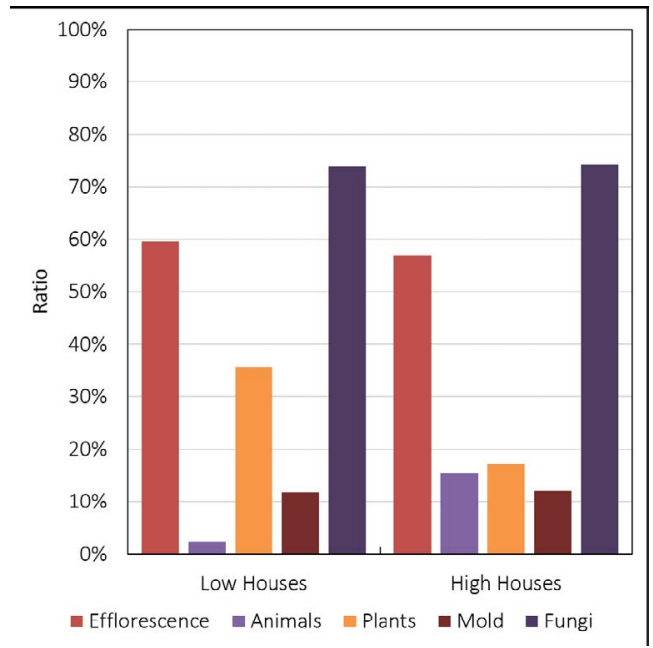

Figure 17. Chemical damages on the walls of colonial houses.
It can be noticed a great difference between the results obtained for $\mathrm{HH}$ and $\mathrm{LH}$, most of the $\mathrm{HH}$ did not exposed chemical damages. However, Figure 18 shows that for LH the ratios were still low compared to other elements of the facade.

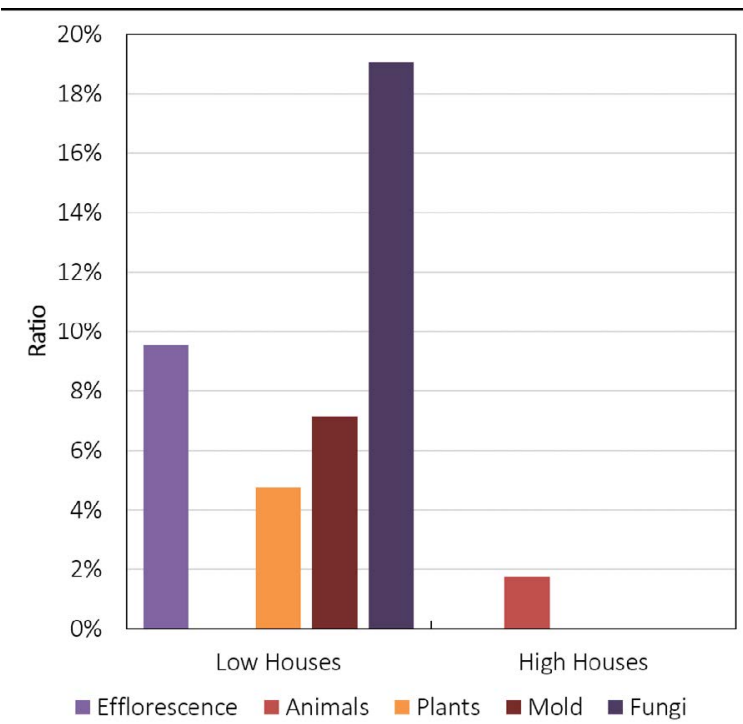

Figure 18. Chemical damages on the windows of colonial houses.

Microorganisms can only settle on the surface of the fronts by means of certain fixation mechanisms which depend on the texture of the attachment surface. Figure 19 shows the results for fronts, which were the less affected by chemical damages.

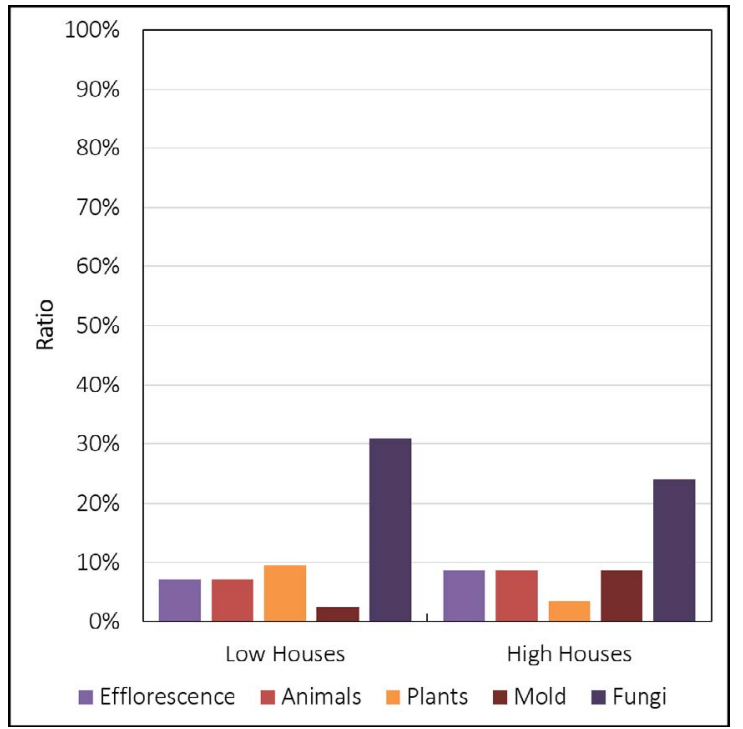

Figure 19. Chemical damages on the fronts of colonial houses. 
Doors did not suffer from chemical damages over the years, Figure 20 shows the results. From an organoleptic point of view, wood fungi are classified in chromomeric and wood-decomposer. They can cause the presence of stains when wood interacts with materials such as nails, lime and wood glue.

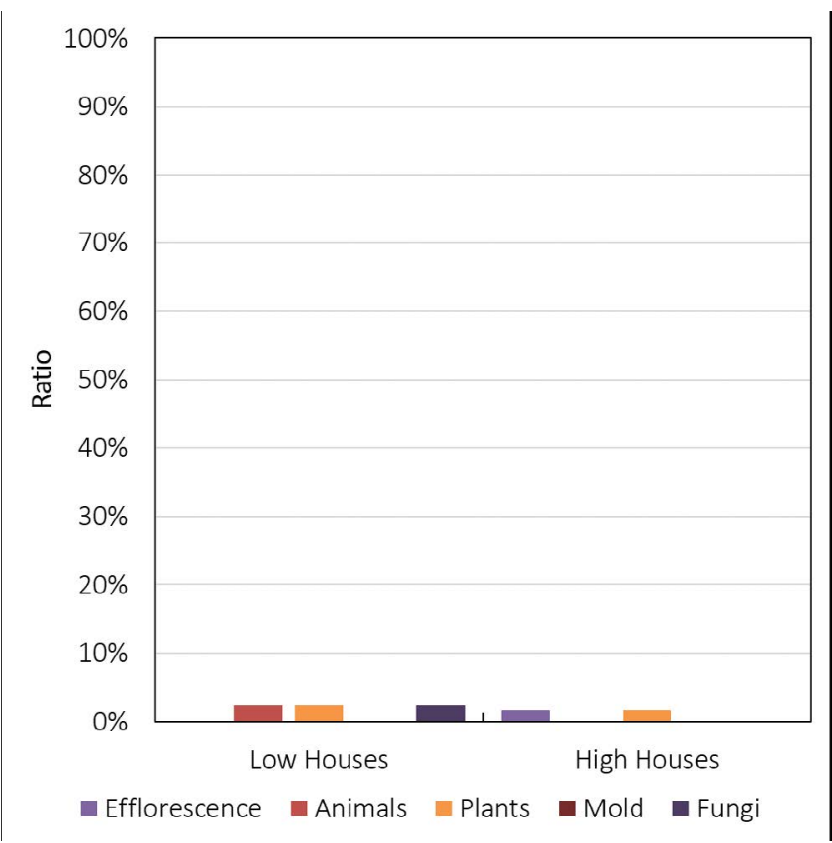

Figure 20. Chemical damages on the doors of colonial houses.

As it can be seen in Figure 21, $46.55 \%$ of balconies exhibited damage by animals, fungi and efflorescence affected $39.65 \%$ and $32.76 \%$ of these elements, respectively. It was also found, that solar radiation has produced darkening of wood until achieving a brownish and subsequently greyish tone. The surface additionally became covered in mold in $17.24 \%$ of the houses, which feed on moisture and photo degradation products within the wood.

Chemical damages in roof shingles exposed low ratios as in the previous elements of colonial houses. Fungi affected $50 \%$ of $\mathrm{HH}$ roof shingles, followed by ratios of efflorescence and plants (Figure 22). During their growth phase, superficial fungi can cause mechanical damage because of the action of hyphae that penetrate the microstructure of ceramic materials. The most evident signals that indicate their presence in a surface are the formation of spots with different macro morphological coloration (pinkish green and dark ash) and unpleasant mold odor impregnating the environment.

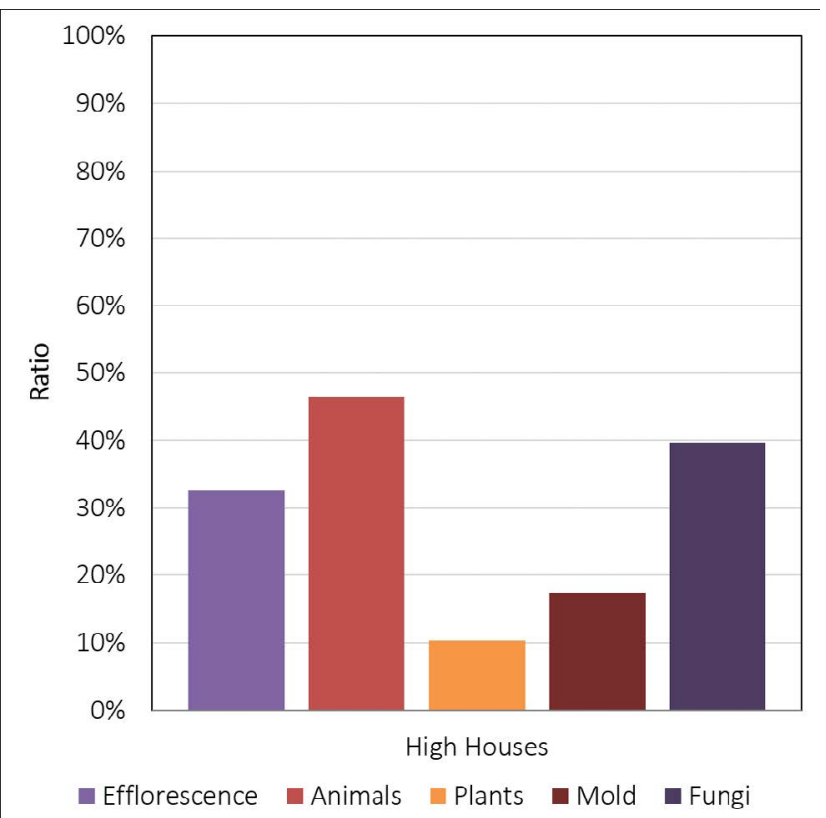

Figure 21. Chemical damages on the covered balconies of colonial houses.

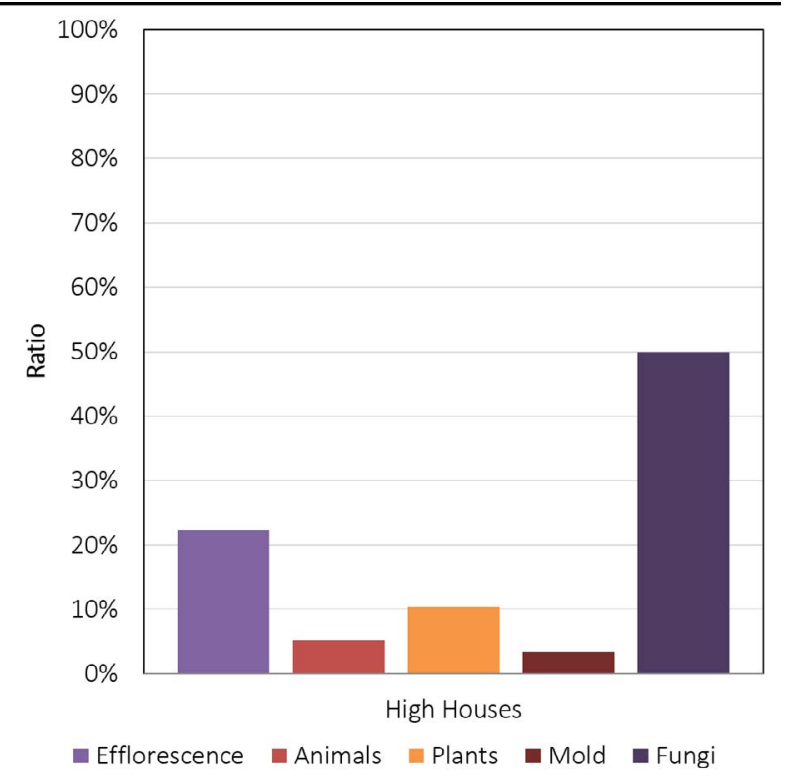

Figure 22. Chemical damages on the roof shingles of colonial houses.

\section{Conclusions}

Based on the results discussed before, it can be affirmed that walls and balconies are the element of colonial houses facades most affected by structural damages, especially those exposed to the direct action of winds. Physical 
damages are the most common of the three types studied followed by mechanical and chemical, respectively. The majority of houses exposed fouling, erosions, fissures, detachments, and fungi. Depending on the class of house certain damages were found, for instance chemical damages ratios were higher for $\mathrm{HH}$ since they have more elements made of wood (balconies)

Finally, the data recollected in this research is a powerful tool for architects dedicated to the maintenance of colonial houses in the city. The information based on pathologically characterization could then be used by interested parties seeking to develop the corresponding interventions

\section{References}

1. Téllez G, Moure E. Arquitectura doméstica Cartagena de Indias. Corporación Nacional de Turismo: Colombia; 1982. p. 22.

2. Cartagena Pregón de la Libertad - Bicentenario Cartagena de Indias 1811-2011 TOMO I. Publicaciones Semana: Colombia; 2011. p. 47-9.

3. Arquitectura cartagenera: 5 siglos de historia. El Universal (Cartagena) [Internet]. [cited 2011 Dec 18]. Available from: http://www.eluniversal.com.co/suplementos/dominical/ arquitectura-cartagenera-5-siglos-de-historia-57900.

4. Atlas histórico de Cartagena de Indias: Paso a paso, la construcción civil, militar religiosa de la ciudad.Banrecultural [Internet]. [cited 2011]. Available from: http://www.banrepcultural.org/biblioteca-virtual/credencial-historia/ numero-143/atlas-historico-de-cartagena-de-indias. Date accessed: 23/19/2011.

5. Broto I. Enciclopedia broto de patologias de la construccion. Leading International; 2007. p. 31-5.

6. Observatorio ambiental de Cartagena de Indias: Precipitación. EPA Cartagena; 2010.

7. Seguimiento de las condiciones meteorológicas y oceanográficas en el Caribe Colombiano. Área Oceanografía Operacional: Dirección General Marítima [Internet]. [cited 2011 Jan 03]. Available from: http://www.cioh.org.co/ meteorologia/pdfcaracterizacion/consultacaracterizacion. php?year $=2006$.

8. Escorcia D, Herrera J, Barbosa G (dir). Caracterización geotécnica del subsuelo y evaluación sísmica en el sector Getsemaní en la ciudad de Cartagena de Indias. University of Cartagena; 2017. p. 1-117. PMid:27270432

9. Determinación de un tama-o muestral [Internet]. [cited 2010 Dec 01]. Available from: http://www.fisterra.com/ mbe/investiga/9muestras/9muestras2.asp. 